\title{
Using Reclaimed Water to Irrigate Turfgrass - Lessons Learned from Research with Phosphorus ${ }^{1}$
}

\author{
George Hochmuth, Jinghua Fan, Jason Kruse, and Jerry Sartain²
}

Municipal wastes are treated at a wastewater treatment facility to produce biosolids and reclaimed water. Reclaimed water that has been treated by filtration and chlorination is safe to use for designated purposes, such as residential landscape irrigation. Florida began using reclaimed water in 1966, and it is a leading state for using reclaimed water. Approximately 660 million gallons of reclaimed water are used every day in Florida (Florida Department of Environmental Protection, 2012), and the state encourages using reclaimed water as an alternative water source to reduce the pressure on potable water supplies.

This publication summarizes the results of a recent research project and provides research-based information for improving nutrient and water management with reclaimed water irrigation of turfgrass. The research described below was supported with funds from the St. Johns River Water Management District and from the Florida Department of Environmental Protection. The information is intended for use by county agents to prepare education materials about the use of reclaimed water for irrigation of landscapes.

Turfgrass in the urban landscape requires appropriate amounts of water and nutrients for optimal growth and health. Residents can benefit from reclaimed water because it satisfies turfgrass irrigation needs for maintaining growth. Reclaimed water also contains nutrients, such as nitrogen $(\mathrm{N})$, phosphorus $(\mathrm{P})$, and potassium $(\mathrm{K})$ that support healthy plant growth. Nutrients in reclaimed water originated largely from human wastes that were treated at the wastewater facility. When reclaimed water is applied to plants, it can offset some of the plants' nutritional needs that would have otherwise been supplied as fertilizer.

We conducted a research project to address questions about using reclaimed water for turfgrass irrigation. We considered the following questions:

- Can turfgrass utilize the $\mathrm{P}$ in reclaimed water?

- How does $\mathrm{P}$ in the reclaimed water and in the soil affect turfgrass growth?

\section{UF/IFAS Research with Reclaimed Water}

The research was conducted in the Envirotron glasshouse at the University of Florida using tap water and reclaimed water from the campus wastewater treatment facility. The research was conducted from July 2011 through August 2012. 'Floratam' St. Augustinegrass (Stenotaphrum secundatum) and 'Empire' Zoysiagrass (Zoysia japonica) turfgrasses were grown from sod supplied by a commercial sod farm and planted on sand media in small ( 38 by $30 \mathrm{~cm} ; 15$ by 12 inches) plastic kitchen tubs (Figure 1). The tubs were fitted with a drainage port at one end to collect leachate.

1. This document is SL390, one of a series of the Soil and Water Science Department, UF/IFAS Extension. Original publication date November 2013. Visit the EDIS website at http://edis.ifas.ufl.edu.

2. George Hochmuth, professor, Soil and Water Science Department; Jinghua Fan, post-doctoral associate, Soil and Water Science Department; Jason Kruse, assistant professor, Environmental Horticulture Department; Jerry Sartain, professor, Soil and Water Science Department; UF/IFAS Extension, Gainesville, FL 32611.

The Institute of Food and Agricultural Sciences (IFAS) is an Equal Opportunity Institution authorized to provide research, educational information and other services only to individuals and institutions that function with non-discrimination with respect to race, creed, color, religion, age, disability, sex, sexual orientation, marital status, national origin, political opinions or affiliations. For more information on obtaining other UF/IFAS Extension publications, contact your county's UF/IFAS Extension office. 


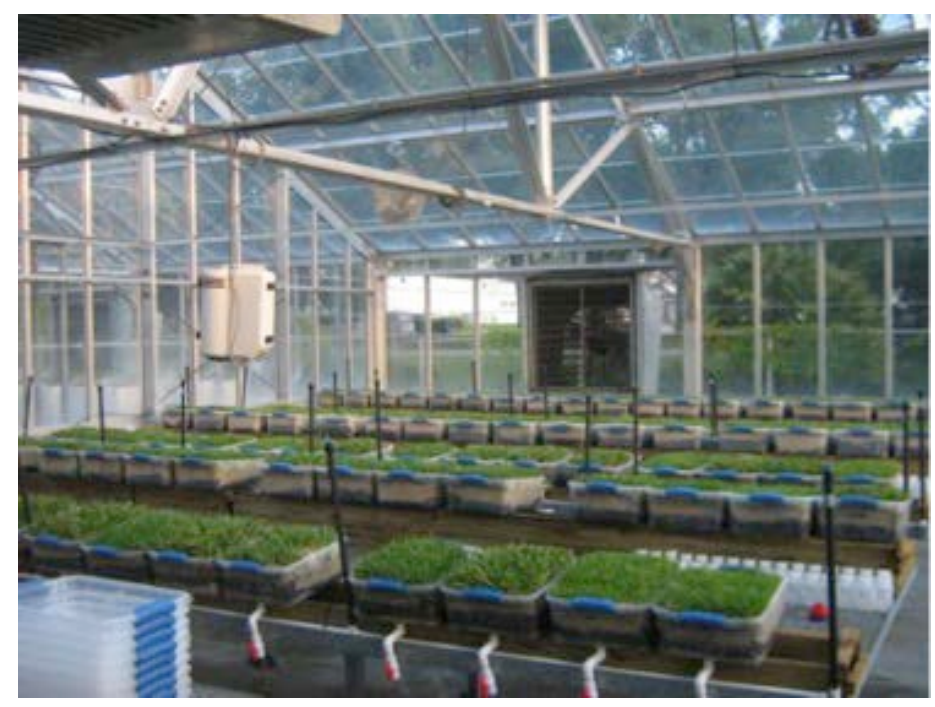

Figure 1. The overview of greenhouse operation showing the growing tubs with the established sod and the drains for collecting leachate. Credits: Dr. Jinghua Fan

For the phosphorus study, we formulated three sand media to grow turfgrass. We gathered sand that contained $2 \mathrm{ppm}$ (parts per million) Mehlich-1 $\mathrm{P}$ from a sand mine near Ocala, Florida. The sand, which was very low in $\mathrm{P}$, was predicted to contribute an insignificant amount of $\mathrm{P}$ for turfgrass nutrition. We combined the sand that was very low in $\mathrm{P}$ with sand high in $\mathrm{P}$ to obtain three sand media of 2 (low), 27 (medium), and 51 ppm (high) Mehlich-1 P. The reclaimed water contained an average of $2 \mathrm{mg} / \mathrm{L}$ total $\mathrm{P}$ and consisted of nearly all ortho-P, which is readily used by plants. During the year, the concentration of $\mathrm{P}$ varied from less than $1 \mathrm{ppm}$ (low concentration) to $4 \mathrm{ppm}$ (high) in the reclaimed water (Figure 2).

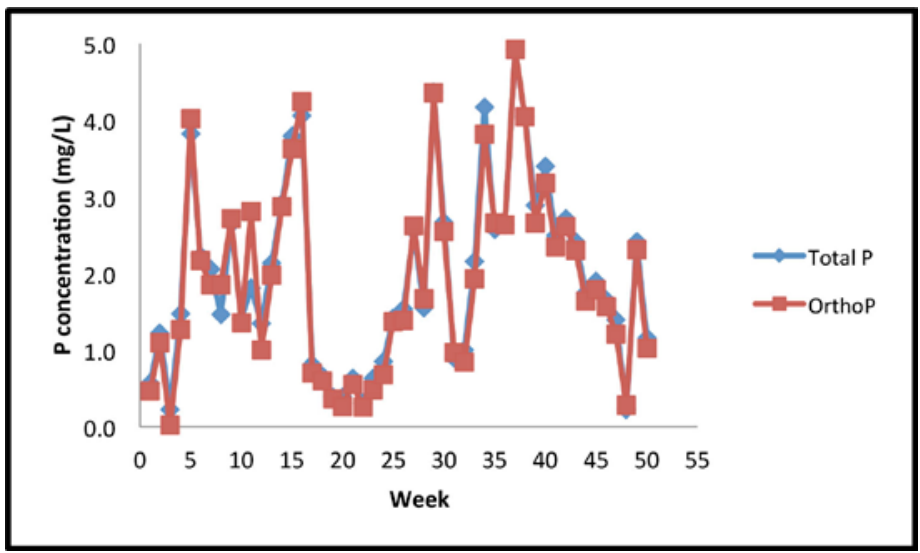

Figure 2. The concentrations of $P$ species in reclaimed water from the University of Florida during July 2011 (week 0) through August 2012 (week 50).

Turfgrass was clipped to measure shoot production on several occasions in the year. During the growing season, a single leaching event was conducted by collecting leachate from the tubs to analyze ortho-P concentrations at the UF/
IFAS Analytical Research Lab. This test was conducted to ultimately test for losses of $\mathrm{P}$ from the turfgrass system. At the end of the research period, sod was harvested from the tubs to measure the root, verdure, and thatch production, and nutrient content of the turfgrass.

\section{Growth Response to Phosphorus in Reclaimed Water}

The level of $\mathrm{P}$ in the sand media was the only factor affecting turfgrass growth. The turfgrass clippings' dry mass grew the least with the very low-P media and grew the greatest with the high-P media; growth was intermediate with the medium-P soil (Figure 3). The water source (reclaimed or tap water) had no effect on clippings production. 'Empire' produced more clippings than 'Floratam.' At the end of the year-long growing period, the dry mass of roots, verdure, and thatch was not affected by treatment. These results indicate the small amount of $P$ supplied from the reclaimed water failed to compensate for the deficit of $\mathrm{P}$ in the sand media that had very low or medium Mehlich-1 P contents.

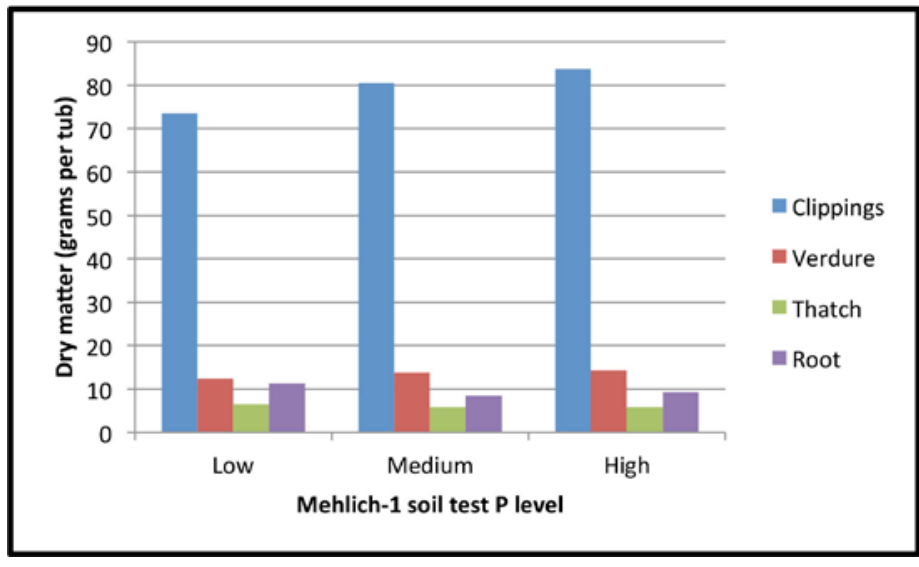

Figure 3. The dry matter accumulation by turfgrass (averaged over two turfgrass types and two water sources). The clippings' dry matter increased with soil-test P level, but the thatch, root, and verdure were not affected.

Turfgrass acquired $\mathrm{P}$ from the media and water combinations (Figures $4 \mathrm{a}$ and $4 \mathrm{~b}$ ). Overall, 'Empire' acquired more P than 'Floratam' St. Augustinegrass. The St. Augustinegrass took up more $\mathrm{P}$ using reclaimed water compared with using tap water, but the difference was small. This was also true for the low- and medium-soil P treatments. However, $\mathrm{P}$ uptake from tap and reclaimed water was similar at the high-soil test $\mathrm{P}$ level. The water source did not influence $\mathrm{P}$ uptake by 'Empire' Zoysiagrass.

When reclaimed water was used as the irrigation source, there was little change in the Mehlich-1 soil test $\mathrm{P}$ concentrations at the end of the growing period (Table 1). When 
tap water was used to irrigate the turfgrass, however, the soil test $\mathrm{P}$ was lower than at the beginning. With the very low $\mathrm{P}$ media, the reclaimed water supplied was enough to maintain the initial soil test P levels, but not add to it. With the tap water treatment, turfgrass reduced the quantity of $\mathrm{P}$ in the sand media. At the end of the growing period, we conducted a leaching event to test the treatment effects on leaching of $\mathrm{P}$. We found that $\mathrm{P}$ leached from this sandy media, and we found no differences among treatments for amounts of $\mathrm{P}$ leached (Table 1). The water source did not affect the amount of $\mathrm{P}$ leached, and the amounts of $\mathrm{P}$ leached were similar across sand media treatments. These results showed that $\mathrm{P}$ can leach from this sand media. While there were no effects of treatments on P leaching from this single-leaching event, results may be different from several, cumulative leaching events.
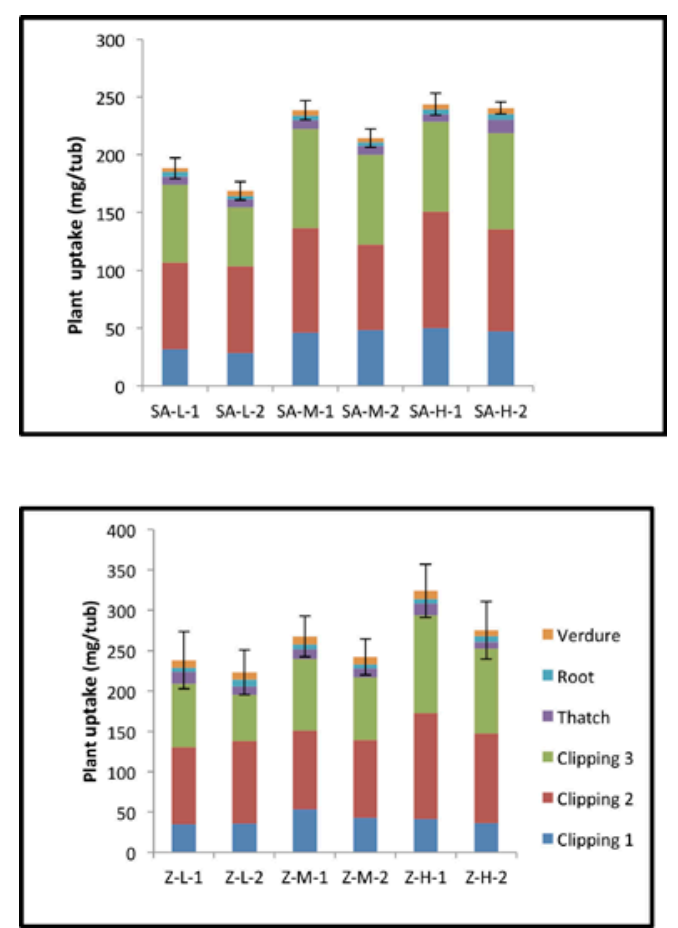

Figure 4. Plant uptake of $\mathrm{P}$ by St. Augustinegrass ( $\mathrm{SA}=\mathrm{Top})$ and Zoysiagrass $(Z=$ Bottom) over the year-long growing period and three clippings collections. The letters $\mathrm{L}, \mathrm{M}$, or $\mathrm{H}$ refer to the sand media $\mathrm{P}$ level - either low, medium, or high. The numbers one and two refer to the water treatment; one for reclaimed water and two for tap water. The standard error bars are for the total plant uptake of $\mathrm{P}$ (sum of clippings, verdure, root, and thatch).
Table 1. Effect of treatments on $\mathrm{P}$ concentration in final soil samples and the leachate at end of experiment

\begin{tabular}{|l|c|c|c|c|}
\hline & \multicolumn{2}{|c|}{$\begin{array}{c}\text { Mehlich-1 soil P (mg } \\
\text { kg-1) }\end{array}$} & \multicolumn{2}{c|}{ Leachate P (ug L-1) } \\
\hline $\begin{array}{c}\text { Soil-P } \\
\text { levels }\end{array}$ & $\begin{array}{c}\text { Reclaimed } \\
\text { water }\end{array}$ & Tap water & $\begin{array}{c}\text { Reclaimed } \\
\text { water }\end{array}$ & Tap water \\
\hline L & 1.7 & 0.9 & 48.2 & 49.0 \\
& $(0.3)^{z}$ & $(0.1)$ & $(10.9)$ & $(15.1)$ \\
\hline M & 25.0 & 19.5 & 55.6 & 55.1 \\
& $(0.9)$ & $(1.3)$ & $(10.3)$ & $(14.5)$ \\
\hline H & 56.2 & 48.0 & 54.6 & 55.0 \\
& $(3.5)$ & $(2.0)$ & $(8.7)$ & $(15.3)$ \\
\hline
\end{tabular}

\section{Summary of Lessons Learned from the Research with Phosphorus}

- The P concentration in reclaimed water can vary during the year, depending on the management activities at the wastewater treatment facility. In order to predict the likelihood of plant responses to $\mathrm{P}$ in the reclaimed water, knowledge of $\mathrm{P}$ concentrations is needed.

- In this one-year study, turfgrass acquired P from reclaimed water. Although more $\mathrm{P}$ was absorbed by turfgrass irrigated with reclaimed water than with tap water, this increased $\mathrm{P}$ uptake did not result in increased growth.

- The turfgrass growing in low-P soil may respond better to added $\mathrm{P}$ fertilizer than to $\mathrm{P}$ from reclaimed water.

- The P level in soil influenced the turfgrass growth more than the $\mathrm{P}$ in reclaimed water. The small amount of $\mathrm{P}$ supplied from the reclaimed water throughout the year could not compensate for the deficit of $\mathrm{P}$ in the sand media that had the very low or medium Mehlich-1 P contents.

- The P leached from this sandy media was during a onetime leaching event. Knowledge is needed regarding a particular soil, and its potential for leaching P. The sandy soil used in this study did not retain all $\mathrm{P}$ applied.

- The $\mathrm{P}$ in reclaimed water helped maintain $\mathrm{P}$ levels in the sand media; this leads to the question of whether $\mathrm{P}$ would buildup in P-retentive soils that are continually irrigated with P-containing reclaimed water. More longer-termed studies are needed to answer this question.

\section{References}

Florida Department of Environmental Protection (FDEP). 2012. 2011 Reuse Inventory. Florida Department of Environmental Protection Reuse Program. http://www.dep.state. fl.us/water/reuse/inventory.htm. 